Institute had been first issued in 1903, and this publication rapidly increased in importance.

Dunstan early recognized the potential educational value of the public exhibition galleries of the Imperial Institute. He secured the appointment of a scientific staff which commenced the reorganisation of the galleries, and under his direction set in train their evolution, which has advanced step by step with the economic and social development of the overseas countries. $\mathrm{He}$ was honorary treasurer and secretary of the Sudeley Committee, and furthered the objects of that body by appointing a guide lecturer in the galleries and encouraging conducted visits of school parties.

By official requests Dunstan visited Cyprus, Asia Minor, Ceylon, India and Newfoundland, and prepared reports on their economic development.

Sir Wyndham, together with Dr. A. Senier, was a founder and a vice-president of the Aristotelian Society. He married as his second wife Violet M. C. Hanbury Tracy, and she survives him.

$$
|2|=
$$

S. E. Chandler

\section{Sir Robert Robertson, K.B.E., F.R.S.}

ROBERT ROBERT YON gssed away on April 28 after a short illness whic ended a very strenuous life. He was working at bi researches in the Davy Faraday Laboratop alust up to the last, although he was in his eightie year. I was first associated with him in 1900 when he was directing the laboratory of the Roy Gunpowder Factory at Waltham Abbey. In those days, almost half a century ago, ideas as to scientific control in manufacture were very modest, and the scale of remuneration was even more modest; and so this important Government factory had a staff of five or six chemists only, and their duties were many and diverse.

While at Waltham Abbey, Robertson carried out an important investigation which cleared up the then obscure question of the stabilization of guncotton, and made it possible to rationalize the method of boiling. Together with his colleague, the late William Rintoul, he worked out in his own time a process and plant for the recovery of the acetone used in the manufacture of cordite, and this was installed in the Royal Gunpowder Factory,

In 1907 he was transferred to the Research Department at Woolwich Arsenal, which had been started a few years before, largely at the instigation of Lord Haldane, as a counterpoise to the German Zentralstelle. There he directed the laboratories, and his work was again concerned principally with explosives. $\mathrm{He}$ continued accurate determinations of the calorimetry of propellants, work which proved of great value during the First World War, when it became necessary to modify the composition of cordite on account of the shortage of acetone. T.N.T. having been adopted for filling high-explosive shells, the manufacturers in Great Britain had difficulty in making enough of it, so Robertson and his staff worked out a process and erected a pilot plant, which was copied on a very large scale at the new factories at Oldbury and Queensferry.

Robertson was elected to the Royal Society in 1917 and was made a K.B.E. in 1918. In 1921 he became Government Chemist, and the range and scope of his activities were greatly extended, but he also found time and energy to carry out researches after hours. With his colleagues he investigated the infra-red spectra of ammonia and phosphine, and so was a pioneer in a branch of physical chemistry which has now become a most important means of investigating molecular structures. $\mathrm{He}$ also made discoveries about the structure of diamonds.

In 1931 he was one of the organisers of the chemical section of the Faraday Centenary Exhibition held at the Albert Hall, London. His acquaintance with research workers and laboratories throughout the kingdom enabled him to help bring together a most interesting lot of exhibits, and he inspired the whole of his staff with his own enthusiasm.

$\mathrm{He}$ retired under the age limit in 1936 , but his activities did not cease, and he continued his researches, now in the Davy Faraday Laboratory; and in 1937 he was appointed director of the Salters' Institute of Industrial Chemistry. The Second World War, however, stopped these researches, as he rejoined the Research Department and took charge of the branch of it which was opened at Swansea. $\mathrm{He}$ also became chairman of several research committees, an activity for which he was specially fitted. After the War he went back to his laboratory bench in Albemarle Street and resumed other activities; but even his vitality was ultimately exhausted.

One of Robertson's greatest fields of work was the Royal Institution, of which he was secretary during 1926-29, and treasurer until 1946. During this time he helped to raise a very large sum for rebuilding practically the whole of the Institution and endowing its work.

Robert Robertson was born at Cupar in 1869. In 1903 he married Kathleen Stannus; he leaves a son and a daughter. Arthur Marshali

\section{Dr. W. J. Perry}

W. J. Perry's interest in anthropology developed while he was reading minematics at Cambridge and had the good forturfo come into close contact with W. H. R. Rivess, vhen the latter was concerned with external sourc of ritual and other cultural features in Melanesiry and was interested in Elliot Smith's stydies archaic ritual in Egypt. Perry took up the why. question of evidence for the survival of elefnents of ancient Egyptian cults, beliefs and institutions in other parts of the world. For a while this was a leisure occupation, but on his invitation to join Elliot Smith at Manchester as reader in comparative religion, he was able to devote himself entirely to these questions, learning Dutch in order to make a detailed study of the Indonesian material, which he published in his first major work, "The Megalithic Culture of Indonesia" (Manchester, 1918).

Perry then proceeded on a programme of much wider scale which sought to demonstrate the diffusion of archaic cults as part of an early cultural complex throughout southern Asia, the Pacific and much of North America. His hypothesis concerning a worldwide archaic culture of predominantly Egyptian origin was set out with a wealth of detail in "The Children of the Sun" (1923), published at the time of his appointment as reader in cultural anthropology in the University of London. Perry's later work in London was increasingly hampered by severe illness, which compelled him to retire in 1939; but he made a number of supplementary studies, notably of the diffusion of agriculture, related crafts and ritual i 
prehistoric Europe in "The Growth of Civilisation" (1924) and of cosmological ideas among Oceanian and other peoples in "The Primordial Ocean" (1935).

It is now generally held that Perry, like Elliot Smith with whom he worked so closely in this field, over-simplified the processes of cultural diffusion, and sometimes too readily assumed that similarities of a general or formal kind, such as the practice of similar crafts or beliefs in sky beings, were indubitable evidence of particular connexions and unitary origins. The insistence on an exclusively Egyptian source for archaic cultural features also unfortunately rendered many of his generalizations unacceptable to specialists on the early cultures of the ancient East, on which new excavations and comparative studies were accumulating a wealth of fresh material. Controversies as to Egyptian versus Sumerian or Babylonian origins often side-tracked the opportunity for collaboration between prehistorians and ethnologists in the comparative study of relations between prehistoric and living civilizations in southern Asia. But the late A. M. Hocart brought strong support for some of Perry's contentions in his comparative studies based on field research on coronation rites and other archaic ceremonials in India, Ceylon and Oceania.

Even though it be held that he claimed too much, Perry's studies established the importance of early centres of higher civilizations as factors in shaping the form and symbolism of human cult and belief over wide areas of so-called primitive culture. In the years that have followed, interest in cultural anthropology in Britain has moved strongly in other directions; but Perry will be remembered for his passionate convictions, his amazing industry, his vigour as a controversialist and not least for his warm humanity as a colleague. DARYLL FORDE

WE regret to any ounce the following deaths :

Dr. Norman R. Campbell, formerly of the Research Laboratories of the General Electric Co., Ltd., Wembley, on May 18, aged sixty-nine.

Mrs. Pernst, widow of Prof. Walther Nernst, For.M.m.R.S., who had been living with her daughter for he past three years in Wimbledon, Surrey, on May 4.

\section{NEWS and VIEWS}

Physical Society's Duddell Medal : Dr. E. H. Land

THE Duddell Miedal for 1949 of the Physical Society was presented on Jung 2 to Dr. Edwin Herbert Land, inventor of the polarizing material 'Polaroid'. Though attempts had boen made by previous workers to replace the costly and limited Nicol prism with dichroic substances in the form of thin laminæ, Land was the first to demonstrate the possibility of manufacturing such laminæ with sub-microscopic dichroic erystzss of quinine iodosulphate correctly oriented to singluate a single erystal extended to a superficial area previously considered impossible. This method is now being superseded as the result of two stages of further development. In the first, a plastic medium is stretched to cause orientation of the micelles. It is then soaked in a solution of the iodonium compound, which is precipitated on the oriented micelles to produce a polarizing medium. In the final method, a stretched plastic medium is treated in a way which converts about 1 per cent of its bulk to a polyvinylene compound, a straight-chain polymer in which the double-bonded oxygen gives the necessary intense directional light absorption. It is claimed that this material is extremely heat-stable and very efficient. The light transmission of the single sheet is about 40 per cent, and is reduced to 0.02 per cent for two sheets in the crossed position. This is a very remarkable development of the original idea. First, Land has succeeded in eliminating the step of orienting sub-microscopic crystals of the iodonium compound; secondly, he has eliminated the compound altogether.

Land has also described an ingenious system of stereoseopic photography in which the two images are formed in two layers of polarizing crystals crossed with respect to each other and mounted on an aluminium background. Stereoscopic pictures on this principle were developed by the Polaroid Corporation under the name of 'vectographs' (J.Opt. Soc. Amer., $30,230 ; 1940)$. A further novel development described by Land is a one-step photographic process, in which the positive print can be produced in about one minute from the time the photograph is taken. In this system, the processing is carried out by feeding the negative and the printing paper between pressure rollers, the reagent being spread in the form of a viscous liquid between the negative and positive emulsions (J. Opt. Soc. Amer., 37, 61 ; 1947).

\section{National Geographic Magazine and Dr. Gilbert Grosvenor}

Dr. GILBERT Grošvenor, president of the National Geographic Sprety of,Washington, D.C., was presenteof th madol aramed after him at a ceremony on Miej $1 \%$, to fols his completing half a century as eajto of the Nutional Geographic Magazine. The A tyazine, which is really of his making, now has a dudution of about two million copies a month. It was in 1899 that the President of the Society at the time was concerned about its official organ, which had only a trivial circulation and no funds behind it. The president in those days, who was A. Graham Bell, of telephone fame, appointed as editor of the Magazine a young, untried, but not untravelled, man. Since then Dr. Grosvenor has built up the reputation and circulation of this finely illustrated journal, which is known throughout the world for the excellence of its photographic illustrations and its colour plates. After five or six precarious years, the corner was turned about 1905 and the circulation steadily grew. Dr. Grosvenor has collected photo. graphs from every corner of the globe and articles by many eminent travellers. He has also edited a series of large-scale detailed political maps issued with the Magazine from time to time, which have a wide circulation and use, and are notable for their accuracy. The profits of this successful publication have been largely devoted to exploration and research in various lands and seas. 